\title{
Development of Highly Active Hydrodesulfurization Catalysts and Effective Usage of Hydrogen Sulfide
}

\author{
Masatoshi SugroKa \\ Dept. of Applied Chemistry, Muroran Institute of Technology, Mizumoto-cho 27-1, Muroran 050
}

(Received January 16, 1990)

\begin{abstract}
This paper deals with the author's systematic studies concerning development of highly active hydrodesulfurization catalysts and effective usage of hydrogen sulfide produced in the hydrodesulfurization process. The author and associates found that reduced metal ion-exchanged $\mathrm{Y}$ zeolites $\left(\mathrm{Me}^{\circ} \mathrm{Y}\right)$ such as $\mathrm{Ni}^{\circ} \mathrm{Y}$ and $\mathrm{Co}^{\circ} \mathrm{Y}$ have tremendous possibilities as highly active hydrodesulfurization catalysts for treatment of petroleum feedstocks. The author also revealed that hydrogen sulfide has some possibilities for effective usage in the production of hydrogen, and as hydrogen donating agent for unsaturated hydrocarbons, promoter for certain kinds of heterogeneous catalytic reactions and modificating agent for solid surfaces, and so forth.
\end{abstract}

\section{Introduction}

Hydrodesulfurization of petroleum feedstocks is one of the important processes in the petroleum industry to produce clean fuels. $\mathrm{CoMo} / \mathrm{Al}_{2} \mathrm{O}_{3}$ and $\mathrm{NiMo} / \mathrm{Al}_{2} \mathrm{O}_{3}$ catalysts have been widely used in hydrodesulfurization process of petroleum. However, recently, the development of catalysts for hydrodesulfurization of petroleum, which are much more active than $\mathrm{CoMo} / \mathrm{Al}_{2} \mathrm{O}_{3}$ and $\mathrm{NiMo} / \mathrm{Al}_{2} \mathrm{O}_{3}$ catalysts, have been claimed in the petroleum industry to produce lower sulfur content fuels, prompted by serious problems of air pollution by $\mathrm{SO}_{x}\left(\right.$ and $\left.\mathrm{NO}_{x}\right)$ caused by burning fossil fuels, which are being aggravated on global scale.

On the other hand, in the hydrodesulfurization process of petroleum, large amounts of hydrogen sulfide are produced, which are finally converted into elementary sulfur and water by Claus process. Since hydrogen sulfide formed in the hydrodesulfurization process is wasted as effluent, the possibilities of the effective usage of hydrogen sulfide would become of great importance from an economic view point.

The author and associates have been systematically investigating the catalytic hydrodesulfurization of organic sulfur compounds over various solid catalysts in order to develop highly active hydrodesulfurization catalysts and, also, the effective usage of hydrogen sulfide, including the recovery of hydrogen from hydrogen sulfide using heterogeneous catalytic technique.

This paper describes the results of our systematic studies, with respect to the development of highly active hydrodesulfurization catalysts and the effective usage of hydrogen sulfide as a total system embodying hydrodesulfurization process of petroleum.

\section{Development of Highly Active Hydrodesulfuri- zation Catalysts}

\subsection{Catalytic Activity of Reduced Metal Y Zeolites for Hydrodesulfurization of Thiophene}

The author and associates have studied catalytic cracking of organic sulfur compounds such as aliphatic thiols and sulfides over various solid catalysts to clarify effective catalysts for the cracking of organic sulfur compounds. We found that solid acid catalysts such as silica-alumina, alumina, solid phosphoric acid, metal fluorides and zeolites were effective for the cracking of organic sulfur compounds ${ }^{1) \sim 14)}$. We, therefore, concluded that solid acid catalysts are effective for the cracking of organic sulfur compounds and that acid site of solid acid catalysts acts as active site for the cracking of organic sulfur compounds. Furthermore, we found that nickel or molybdenum supported on acidic carriers such as silica-alumina and alumina showed high catalytic activity for the hydrodesulfurization of thiophene15) 17). From these results, we concluded that bifunctional catalysts, which have the nature of both metal and solid acid catalysts, are effective for hydrodesulfurization of thiophene, and high dispersion of metal particles is also an important factor of highly active hydrodesulfurization catalysts. The author and associates focused attention to reduced metal ion-exchanged $\mathrm{Y}$ zeolites $\left(\mathrm{Me}^{\circ} \mathrm{Y}\right)$.

It is generally accepted that the metal ions in MeY zeolites are reduced by hydrogen into highly 
dispersed zero valent metal particles, which form a new acidic hydroxyl groups, i.e., Brönsted acid site, according to the following equation:

$$
\begin{aligned}
\mathrm{Me}^{\mathrm{X}}+\left(\mathrm{O}^{-}-\mathrm{Zeol}\right)_{x}+\frac{\mathrm{x}}{2} \mathrm{H}_{2} \\
\longrightarrow \mathrm{xH}^{+} \mathrm{O}^{-}-\mathrm{Zeol}+\mathrm{Me}^{\circ}
\end{aligned}
$$

where $\left(\mathrm{O}^{-}-\mathrm{Zeol}\right)_{x}$ and $\mathrm{H}^{+} \mathrm{O}^{-}-\mathrm{Zeol}$ represent the zeolite lattice and the surface acidic hydroxyl groups, respectively.

Since it has been revealed that the reduced MeY zeolites $\left(\mathrm{Me}^{\circ} \mathrm{Y}\right)$ act as bifunctional catalysts in hydrocracking of hydrocarbons, we expected that reduced MeY zeolites would also act as effective hydrodesulfurization catalysts for removal of organic sulfur compounds. Thus, we investigated the hydrodesulfurization of thiophene over various $\mathrm{Me}^{\circ} \mathrm{Y}$ zeolites for the purpose of development of highly active hydrodesulfurization catalysts for treatment of petroleum feedstocks ${ }^{18) ~ 23)}$.

The catalytic activities of reduced MeY zeolites in the hydrodesulfurization of thiophene were examined at $400^{\circ} \mathrm{C}$ using the pulse reaction method. The catalytic activities of various $\mathrm{Me}^{\circ} \mathrm{Y}$ zeolites for the hydrodesulfurization of thiophene at $400^{\circ} \mathrm{C}$ are shown in Fig. 1. It was found that some of the $\mathrm{Me}^{\circ} \mathrm{Y}$ zeolites such as $\mathrm{Ni}^{\circ} \mathrm{Y}, \mathrm{Co}^{\circ} \mathrm{Y}$, $\mathrm{Ag}^{\circ} \mathrm{Y}$ and $\mathrm{Cu}^{\circ} \mathrm{Y}$ were active in the hydrodesulfurization of thiophene. The products of hydrodesulfurization of thiophene over these $\mathrm{Me}^{\circ} \mathrm{Y}$ zeolites consisted of hydrogen sulfide and low molecular weight hydrocarbons such as methane,

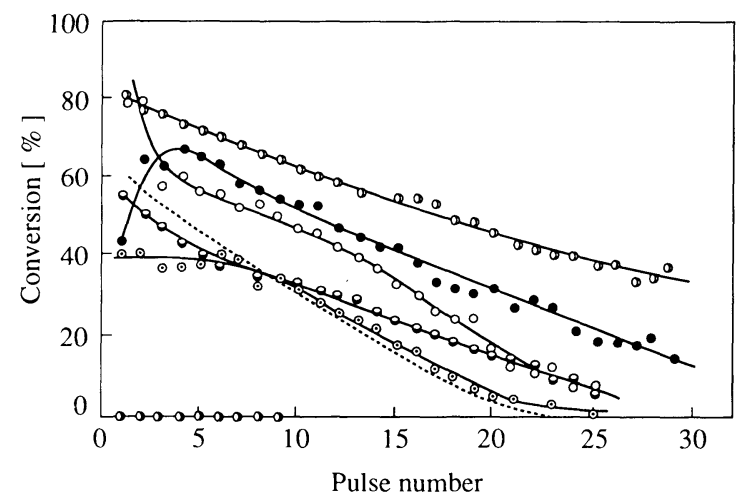

: $\mathrm{Co}^{\circ} \mathrm{Y}$ (71.4), O: $\mathrm{Ni}^{\circ} \mathrm{Y}$ (68.8), ○: $\mathrm{Cu}^{\circ} \mathrm{Y}(77.3), \odot$ $\mathrm{Ag}^{\circ} \mathrm{Y}$ (93.9), $\mathrm{O}: \mathrm{Fe}^{\circ} \mathrm{Y}$ (92.9), $\mathrm{Cr}^{\circ} \mathrm{Y}$ (98.3), (1: $\mathrm{Co}^{\circ} \mathrm{Y}$ presulfurized by $2 \mathrm{cc}$ of $\mathrm{H}_{2} \mathrm{~S}$ at $400^{\circ} \mathrm{C}$

Dollted line represents the activity change of $\mathrm{HY}$ zeolite (78.6\%) in the desulfurization of thiophene.

Fig. I Catalytic Activities of Reduced Metal Y Zeolites $\left(\mathrm{Me}^{\circ} \mathrm{Y}\right)$ for Hydrodesulfurization of Thiophene at $400^{\circ} \mathrm{C}$ (Numbers in parentheses represnt the percentage of ion-exchange.) ethylene, propylene, butenes and butanes. The order of maximal catalytic activity of $\mathrm{Me}^{\circ} \mathrm{Y}$ was as follows:

$$
\mathrm{Ni}^{\circ} \mathrm{Y}>\mathrm{Co}^{\circ} \mathrm{Y}>\mathrm{Cu}^{\circ} \mathrm{Y}>\mathrm{Ag}^{\circ} \mathrm{Y}>\mathrm{Fe}^{\circ} \mathrm{Y}, \quad \mathrm{Cr}^{\circ} \mathrm{Y} \approx 0
$$

The catalytic activities of $\mathrm{Me}^{\circ} \mathrm{Y}$ zeolites except those of $\mathrm{Co}^{\circ} \mathrm{Y}$ decreased gradually as pulse number progressed. For hydrodesulfurization of thiophene over $\mathrm{Co}^{\circ} \mathrm{Y}$, the maximal activity was observed at some pulse number after the first pulse. However, the initial activity of $\mathrm{Co}^{\circ} \mathrm{Y}$ at the first pulse was remarkably enhanced by pretreatment with $2 \mathrm{ml}$ of hydrogen sulfide as shown in Fig. 1. This result is closely related to the activity of $\mathrm{MeY}$ zeolites enhanced by pretreatment with hydrogen sulfide in acid-catalyzed reactions described in later section 3.4. The order of catalytic activity of $\mathrm{Me}^{\circ} \mathrm{Y}$ matches the order of $\mathrm{H}_{2}$ adsorptive ability of these metals, excepting iron and chromium. It was, therefore, found that the catalytic activity of $\mathrm{Me}^{\circ} \mathrm{Y}$ for hydrodesulfurization of thiophene is mainly controlled by the difference in $\mathrm{H}_{2}$-adsorptive ability of metals in $\mathrm{Me}^{\circ} \mathrm{Y}$ zeolites.

On the other hand, we examined the activity of hydrogen $\mathrm{Y}$ zeolite(HY) for the desulfurization of thiophene at $400{ }^{\circ} \mathrm{C}^{19}$. The result was positive. The main desulfurizaion product was hydrogen sulfide, but a trace amount of unidentified carbonaceous compound had also formed. The conversion of thiophene on $\mathrm{HY}$ decreased as the pulse number progressed, and finally it became zero as shown by dotted line in Fig. 1. This result indicates that the Brönsted acid site acts as another active site in hydrodesulfurization of thiophene over reduced MeY zeolites. The author and associates concluded, therefore, that both $\mathrm{H}_{2}$ adsorptive ability of metals and the Brönsted acid site are necessary for highly active $\mathrm{Me}^{\circ} \mathrm{Y}$ hydrodesulfurization catalysts.

The catalytic activity of $\mathrm{Me}^{\circ} \mathrm{Y}$ zeolites in the hydrodesulfurization of thiophene decreased as pulse number progressed. The decreased catalytic activity of $\mathrm{Me}^{\circ} \mathrm{Y}$, relative to pulse number, was regenerated by calcination at $500^{\circ} \mathrm{C}$ in an oxygen stream. This result indicates that the cause of catalyst deactivation of $\mathrm{Me}^{\circ} \mathrm{Y}$ with progression of pulse number is the accumulation of carbonaceous deposits on the catalyst surface. The catalyst deactivation of $\mathrm{Ni}^{\circ} \mathrm{Y}$ and $\mathrm{Co}^{\circ} \mathrm{Y}$ with progress of pulse number was remarkably improved by increasing calcination temperature of $\mathrm{NiY}$ and $\mathrm{CoY}$ in air prior to reduction. $\mathrm{NiY}$ and $\mathrm{CoY}$ calcined at $800^{\circ} \mathrm{C}$ showed no catalytic activity, however, because crystal structure of zeolite had 


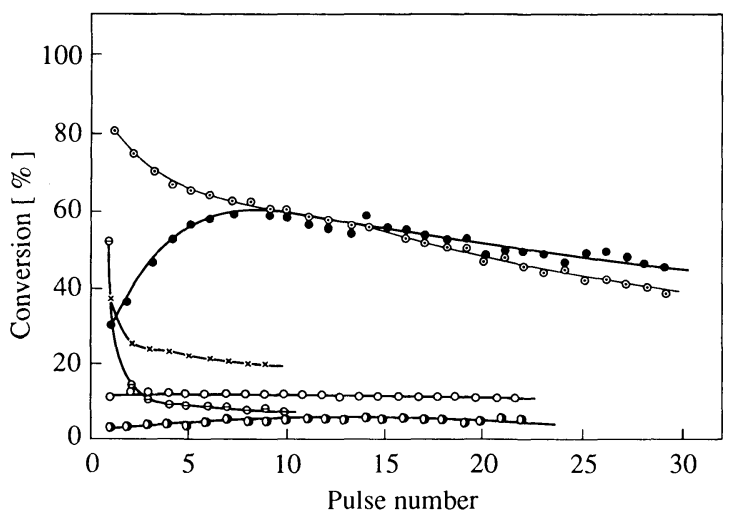

$\odot: \mathrm{Ni}^{\circ} \mathrm{Y}-700, \quad \bigcirc: \mathrm{Co}^{\circ} \mathrm{Y}-600, \quad 0: \mathrm{CoO}-\mathrm{MoO} / \mathrm{Al}_{2} \mathrm{O}_{3}$ (Girdler G-35B), O: $\mathrm{CoO}-\mathrm{MoO} / \mathrm{Al}_{2} \mathrm{O}_{3}$ (Ketjenfine $\mathrm{K}-124), \ominus: \mathrm{Ni}(5 \mathrm{wt} \%)-\mathrm{SiO}_{2} \cdot \mathrm{Al}_{2} \mathrm{O}_{3}, \mathrm{X}: \mathrm{Mo}(5 \mathrm{wt} \%)-\mathrm{SiO}_{2}$. $\mathrm{Al}_{2} \mathrm{O}_{3}$

Fig. 2 Comparison of Catalytic Activities of $\mathrm{Ni}^{\circ} \mathrm{Y}$ and $\mathrm{Co}^{\circ} \mathrm{Y}$ with Those of Various Kinds of Catalysts for Hydrodesulfurization of Thiophene at $400^{\circ} \mathrm{C}$

been destroyed.

Since $\mathrm{Ni}^{\circ} \mathrm{Y}$ and $\mathrm{Co}^{\circ} \mathrm{Y}$ calcined at $700{ }^{\circ} \mathrm{C}$ and $600^{\circ} \mathrm{C}\left(\mathrm{Ni}^{\circ} \mathrm{Y}-700\right.$ and $\left.\mathrm{Co}^{\circ} \mathrm{Y}-600\right)$, respectively, showed high and relatively stable catalytic activity in hydrodesulfurization of thiophene, the catalytic activities of these two $\mathrm{Me}^{\circ} \mathrm{Y}$ zeolites were compared with those of nickel and molybdenum catalysts supported on silica-alumina $\left(\mathrm{Ni}-\mathrm{SiO}_{2} \cdot \mathrm{Al}_{2} \mathrm{O}_{3}\right.$ and $\mathrm{Mo}-\mathrm{SiO}_{2} \cdot \mathrm{Al}_{2} \mathrm{O}_{3}$ ) and commercially available $\mathrm{CoMo} /$ $\mathrm{Al}_{2} \mathrm{O}_{3}$ catalysts (Girdler $\mathrm{G}-35$ and Ketjenfine $\mathrm{K}-125)$ to explore the possibility of utilizing the $\mathrm{Me}^{\circ} \mathrm{Y}$ zeolites as industrial hydrodesulfurization catalysts. The activities of various solid catalysts for hydrodesulfurization of thiophene under same experimental conditions are shown in Fig. 2. It was found that the $\mathrm{Ni}^{\circ} \mathrm{Y}-700$ and $\mathrm{Co}^{\circ} \mathrm{Y}-600$ showed higher catalytic activities than those of $\mathrm{Ni}-\mathrm{SiO}_{2} \cdot \mathrm{Al}_{2} \mathrm{O}_{3}, \mathrm{Mo}-\mathrm{SiO}_{2} \cdot \mathrm{Al}_{2} \mathrm{O}_{3}$ and commercially available Mo based hydrodesulfurization catalysts, as shown in Fig. $\mathbf{2}^{20}$. From these results, the author and associates concluded that there is a possibility of using $\mathrm{Me}^{\circ} \mathrm{Y}$ zeolites as highly active hydrodesulfurization catalysts for the treatment of petroleum feedstocks.

\subsection{Mechanism of Hydrodesulfurizatin of Thio- phene over $\mathrm{Me}^{\circ} \mathbf{Y}$ Zeolites}

It was found that $\mathrm{Ni}^{\circ} \mathrm{Y}$ and $\mathrm{Co}^{\circ} \mathrm{Y}$ zeolites showed high catalytic activity in the hydrodesulfurizaton of thiophene. We investigated the mechanism of the hydrodesulfurization of thiophene over reduced NiY and CoY zeolites by use of infrared spectroscopic method ${ }^{21)} 23$ ).

The infrared spectra of thiophene adsorbed on reduced $\mathrm{NiY}$ at room temperature followed by

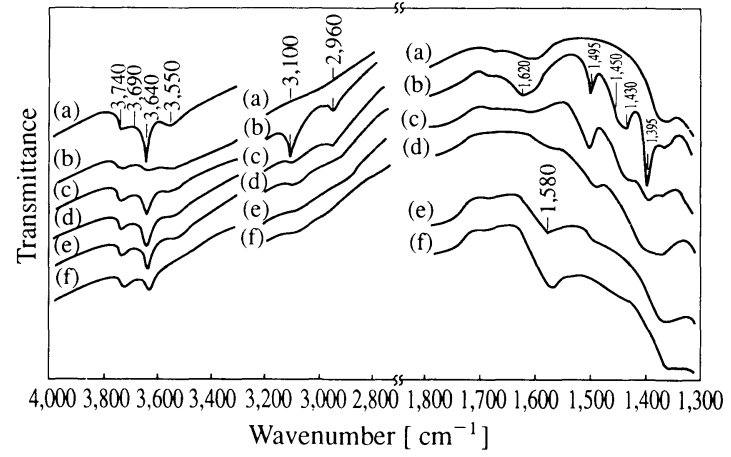

(a) $\mathrm{NiY}$ reduced at $450^{\circ} \mathrm{C}$ for $2 \mathrm{~h} . \mathrm{Ni}^{\circ} \mathrm{Y}$ after thiophene adsorption at room temperature followed by evacuation at (b) room temp., (c) $120^{\circ} \mathrm{C}$, (d) $200^{\circ} \mathrm{C}$, (e) $300^{\circ} \mathrm{C}$, (f) $400^{\circ} \mathrm{C}$

Fig. 3 Effect of Heating on Infrared Spectra of Thiophene Adsorbed on $\mathrm{Ni}^{\circ} \mathrm{Y}$

evacuation at different temperatures as shown in Fig. 3. A marked decrease in intensity of the strong band of acidic hydroxyl group at $3,640 \mathrm{~cm}^{-1}$ was observed by adsorption of thiophene as shown in the spectra $(b)$. It was revealed that there is strong interaction between acidic hydroxyl group on reduced NiY surface and adsorbed thiophene. In the spectra(b), the absorption band of streching vibration of unsaturated $(=\mathrm{CH}-)$ and saturated $\left(-\mathrm{CH}_{2}-\right)$ of $\mathrm{C}-\mathrm{H}$ groups at $3,100 \mathrm{~cm}^{-1}$ and 2,960 $\mathrm{cm}^{-1}$ and deformation vibration of $\mathrm{C}-\mathrm{H}$ group at $1,450,1,430$ and $1,395 \mathrm{~cm}^{-1}$ were observed. On the other hand, a strong band appeared at 1,620 and $1,495 \mathrm{~cm}^{-1}$ in the adsorption of thiophene. These bands were assigned to the out-of-plane mode of $\mathrm{C}-\mathrm{H}$ group of adsorbed thiophene ring and $\mathrm{C}=\mathrm{S}$ double bond. As the evacuation temperature increased, intensities of following absorption bands of $\mathrm{C}=\mathrm{S}$ double bond at $1,495 \mathrm{~cm}^{-1}$, out-ofplane mode of $\mathrm{C}-\mathrm{H}$ group in thiophene ring at $1,620 \mathrm{~cm}^{-1}$, and $\mathrm{C}-\mathrm{H}$ groups at 3,100, 2,960, 1,450, $1,430,1,395 \mathrm{~cm}^{-1}$ decreased, but a large and broad band near $1,580 \mathrm{~cm}^{-1}$ had appeared. The broad band near $2,580 \mathrm{~cm}^{-1}$ was assigned to the precursor of carbonaceous deposit, probably polyene species $+\mathrm{CH}=\mathrm{CH}+{ }_{n}$ which result from polymerization of diene species. The band of hydroxyl group which disappeared at $3,640 \mathrm{~cm}^{-1}$ by adsorption of thiophene had gradually regenerated as evacuation temperature was raised as shown in the spectra (c)-(f).

From the results of the infrared spectra of thiophene adsorbed on reduced NiY zeolite, we concluded that reaction mechanism in hydrodesulfurization of thiophene on reduced $\mathrm{MeY}$ zeolites is represented as shown below: 


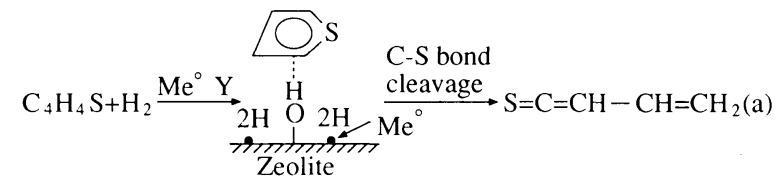

$\underset{\begin{array}{l}\text { Hydrodesulfuri- } \\ \text { zation }\end{array}}{\stackrel{2 \mathrm{H}_{2}}{\mathrm{H}_{2} \mathrm{~S}}} \mathrm{CH}_{2}=\mathrm{CH}-\mathrm{CH}=\mathrm{CH}_{2}(\mathrm{a}) \stackrel{\bigcup_{\text {Hydrogenation }}^{\mathrm{H}_{2}}}{\longrightarrow}\left\{\begin{array}{l}\text { Butene isomers } \\ \text { Butane }\end{array}\right.$

$\underset{\text { Hydrocracking }}{\stackrel{\mathrm{H}_{2}}{\mathrm{C}_{1}}-\mathrm{C}_{3} \text { hydrocarbons }}$

By this mechanism, thiophene is adsorbed on reduced MeY zeolites by strong interaction with acidic hydroxyl group, maintaining a planar structure. The acidic hydroxyl group, i.e., Brönsted acid site, acts as the active site for cleavage of the $\mathrm{C}-\mathrm{S}$ bond of the thiophene ring to form a reaction intermediate with $\mathrm{C}=\mathrm{S}$ double bond like $\mathrm{S}=\mathrm{C}=\mathrm{CH}-$ $\mathrm{CH}=\mathrm{CH}_{2}$. Hydrogen is indepenuently adsorbed dissociatively on the metal or metal sulfide particles. The adsorbed species with $\mathrm{C}=\mathrm{S}$ double bond are hydrogenated or hydrocracked to form hydrogen sulfide and various hydrocarbon products such as methane, ethylene, propylene, butenes and butanes by the attack of hydrogen atom dissociated on metal or metal sulfide particles.

On the basis of this mechanism, much more active $\mathrm{Me}^{\circ} \mathrm{Y}$ catalysts for usage in the hydrodesulfurization of petroleum feedstocks could be prepared by loading metal or metal particles with high dispersion, which are extremely effective in hydrogenation of hydrocarbon species, in the presence of hydrogen sulfide, on strongly acidic zeolites.

\section{Effective Usage of Hydrogen Sulfide}

\subsection{Recovery of Hydrogen by Catalytic Decom- position of Hydrogen Sulfide}

Recently, some attempts have been made to recover hydrogen from hydrogen sulfide by catalytic decomposition of hydrogen sulfide ${ }^{35}$. It has been revealed that only $\mathrm{MoS}_{2}$ and $\mathrm{WS}_{2}$ act as catalyst in the decomposition of hydrogen sulfide ${ }^{38)}$.

The author and associates investigated the decomposition of hydrogen sulfide over various $\mathrm{MoS}_{2}$ based catalysts, using closed circulation system, to develop effective catalysts for recovery of hydrogen from hydrogen sulfide ${ }^{24) \sim 26)}$. The catalytic decomposition of hydrogen sulfide over various supported $\mathrm{MoS}_{2}$ catalysts at $500^{\circ} \mathrm{C}$ is shown in Fig. 4. It was found that $\mathrm{MoS}_{2}$ supported on alumina showed the highest activity in the decomposition of hydrogen sulfide, and alumina was the most effective as carrier for $\mathrm{MoS}_{2}$ catalyst.

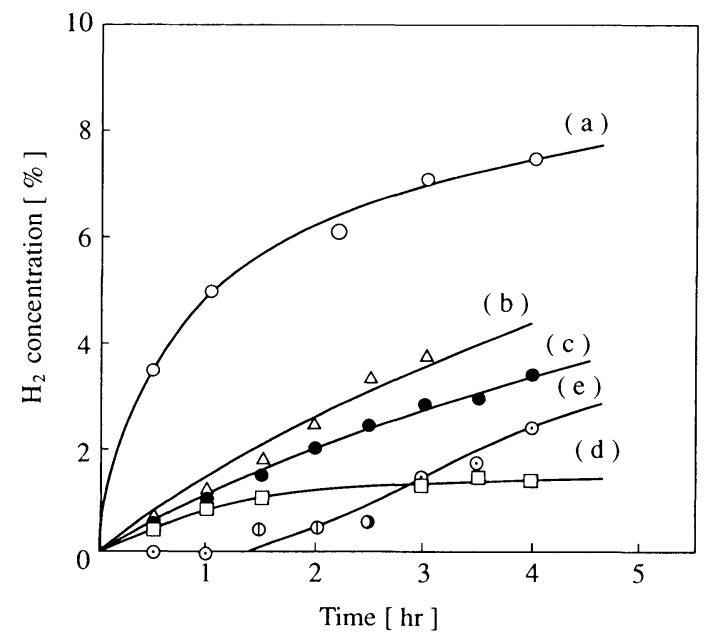

(a): $\mathrm{MoS}_{2} / \gamma-\mathrm{Al}_{2} \mathrm{O}_{3}$, (b): $\mathrm{MoS}_{2} / \alpha-\mathrm{Al}_{2} \mathrm{O}_{3}$, (c): $\mathrm{MoS}_{2} /$ quartz, (d): $\mathrm{MoS}_{2} / \mathrm{NaY}$, (e): $\mathrm{MoS}_{2} / \gamma-\mathrm{Al}_{2} \mathrm{O}_{3}-\mathrm{K}$

Fig. 4 Decomposition of Hydrogen Sulfide over Various Supported $\mathrm{MoS}_{2}$ Catalysts at $500^{\circ} \mathrm{C}$

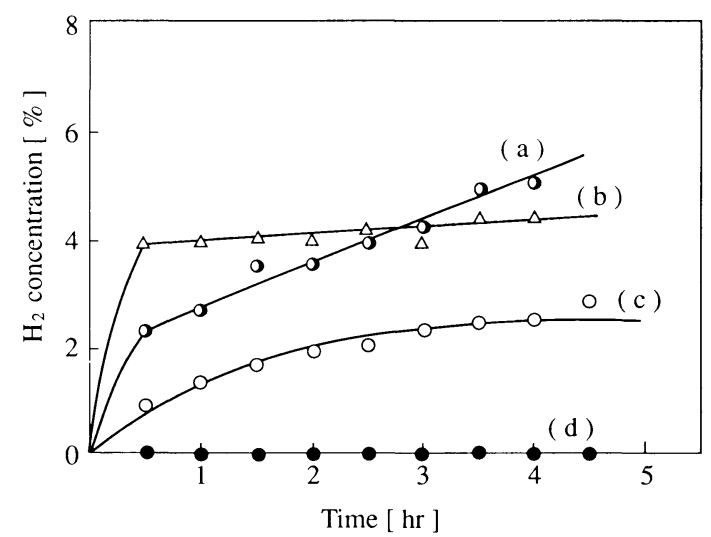

(a): $\mathrm{CoMo} / \mathrm{Al}_{2} \mathrm{O}_{3}, \quad$ (b): $\mathrm{NiMo} / \mathrm{Al}_{2} \mathrm{O}_{3}$ (c): $\mathrm{Mo} / \mathrm{Al}_{2} \mathrm{O}_{3}$, (d): quartz

Fig. 5 Decomposition of Hydrogen Sulfide over Mo Based Hydrodesulfurization Catalysts at $500^{\circ} \mathrm{C}$

The catalytic decomposition of hydrogen sulfide over various commercially available Mo based hydrodesulfurization catalysts is shown in Fig. 5. It was revealed that sulfided $\mathrm{CoMo} / \mathrm{Al}_{2} \mathrm{O}_{3}$ catalyst was effective in the recovery of hydrogen from hydrogen sulfide by the catalytic decomposition of hydrogen sulfide.

The author and associates also studied in more detail the catalytic decomposition of hydrogen sulfide over $\mathrm{MoS}_{2}$ at $500{ }^{\circ} \mathrm{C}$, in order to clarify the mechanism of catalytic decomposition of hydrogen sulfide over $\mathrm{MoS}_{2}$ based catalysts. The catalytic decomposition of hydrogen sulfide over $\mathrm{MoS}_{2}$ at $500^{\circ} \mathrm{C}$ is shown in Fig. 6. Only slight increase of pressure of hydrogen over quartz sand at $500^{\circ} \mathrm{C}$ was observed as shown in Fig. 6. The pressure of hydrogen, however, remarkably increased with 
reaction time, it was observed, in the decomposition of hydrogen sulfide over $\mathrm{MoS}_{2}$ evacuated at $500^{\circ} \mathrm{C}$. The catalytic activity of $\mathrm{MoS}_{2}$ was much greater enhanced by reduction with hydrogen at $500^{\circ} \mathrm{C}$ as shown in Fig. 6. The catalytic activity of $\mathrm{MoS}_{2}$ was further enhanced with a raise in the reduction temperature as shown in Fig. 7. From these results, we concluded that coordinatively unsaturated site of $\mathrm{MoS}_{2}$, formed by evacuation or reduction at high temperatures, acts as the active site for the decomposition of hydrogen sulfide. On the basis of this conclusion, the authors advanced the following reaction mechanism in the catalytic decomposition of hydrogen sulfide over $\mathrm{MoS}_{2}$ :

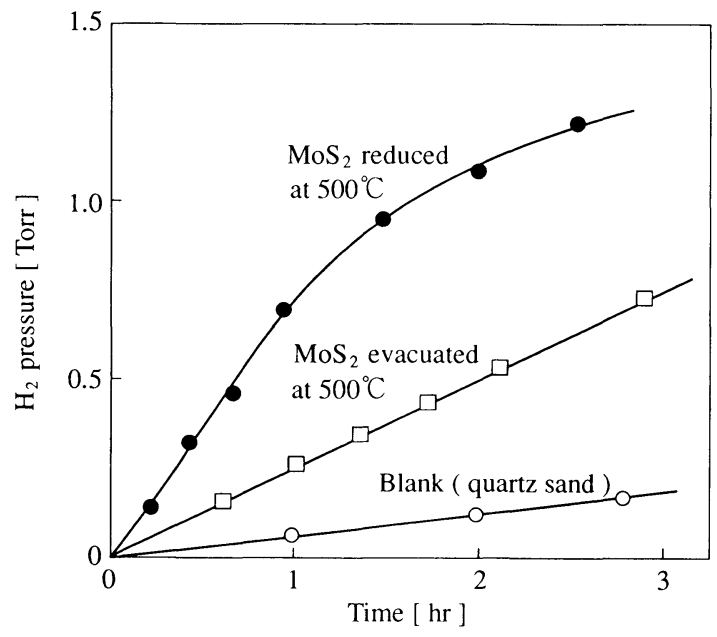

Fig. 6 Decomposition of $\mathrm{H}_{2} \mathrm{~S}$ over $\mathrm{MoS}_{2}$ Catalyst at $500^{\circ} \mathrm{C}$

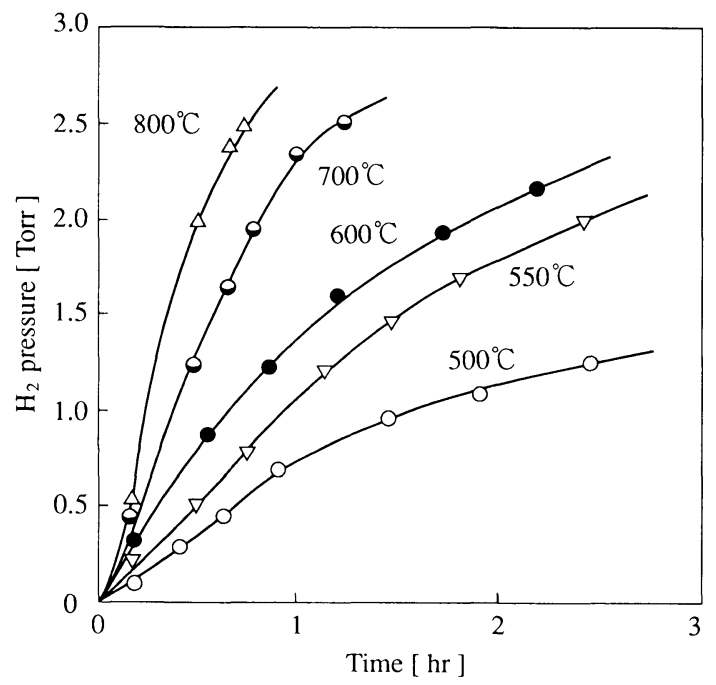

Fig. 7 Effect of Reduction Temperature on the Catalytic Activity of $\mathrm{MoS}_{2}$ for the Decomposition of $\mathrm{H}_{2} \mathrm{~S}$

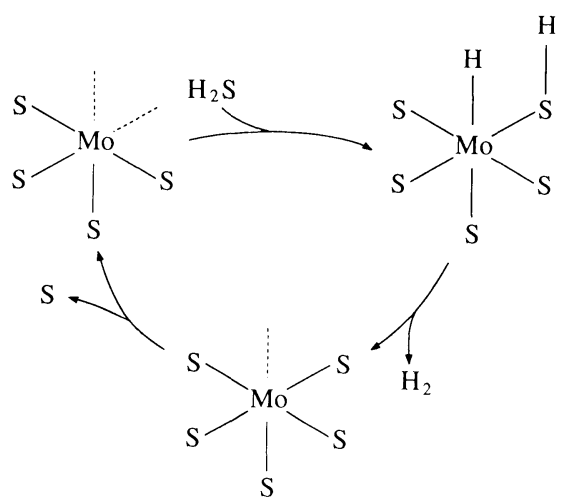

( 3 )

The authors also advanced a similar reaction mechanism for the decomposition of hydrogen sulfide over sulfided $\mathrm{CoMo} / \mathrm{Al}_{2} \mathrm{O}_{3}$ catalyst, in which alumina and cobalt sulfide in the catalyst system act as promoter for $\mathrm{MoS}_{2}{ }^{26)}$.

\subsection{Catalytic Hydrogenation of Olefins with Hydrogen Sulfide}

The author and associates investigated the hydrogenation of olefins with hydrogen sulfide over sulfided $\mathrm{Mo} / \mathrm{Al}_{2} \mathrm{O}_{3}$ catalyst by use of a closed circulation system in order to develop alternative effective usage of hydrogen sulfide ${ }^{27)}$.

The reaction of 1,3-butadiene with hydrogen sulfide at $200^{\circ} \mathrm{C}$ is shown in Fig. 8. It was found that hydrogenation of 1,3-butadiene to form various butene isomers occurred at $200^{\circ} \mathrm{C}$. Butane was not formed, however, even after all 1,3-butadiene in gas phase had been completely consumed. This is unique phenomenon observed in the hydrogenation of 1,3-butadiene with hydrogen sulfide, as compared with hydrogenation of hydrogen.

The reaction of propylene with hydrogen sulfide at $400^{\circ} \mathrm{C}$ is shown in Fig. 9. Substantial amount

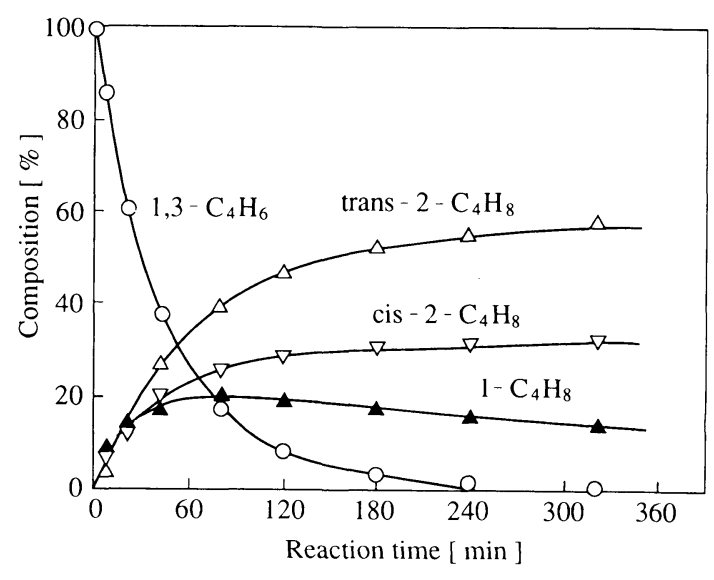

1,3- $\mathrm{C}_{4} \mathrm{H}_{6}=25$ Torr, $\mathrm{H}_{2} \mathrm{~S}=50$ Torr

Fig. 8 Hydrogenation of 1,3-Butadiene with Hydrogen Sulfide over Sulfided $\mathrm{Mo} / \mathrm{Al}_{2} \mathrm{O}_{3}$ Catalyst at $200^{\circ} \mathrm{C}$ 


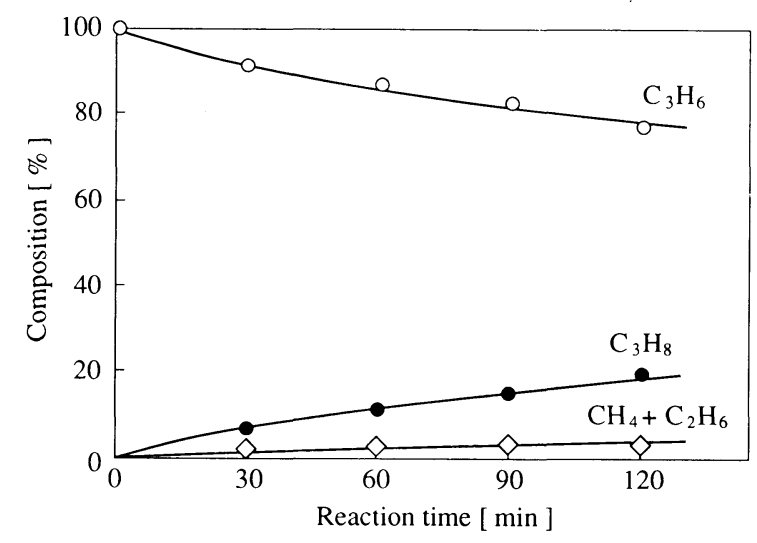

$\mathrm{C}_{3} \mathrm{H}_{6}=50$ Torr, $\mathrm{H}_{2} \mathrm{~S}=70$ Torr

Fig. 9 Hydrogenation and Hydrogenolysis of Propylene with Hydrogen Sulfide over Sulfided $\mathrm{Mo} / \mathrm{Al}_{2} \mathrm{O}_{3}$ Catalyst at $400^{\circ} \mathrm{C}$

of propane and small amounts of methane and ethane were formed. These indicate that main reaction of propylene with hydrogen sulfide is hydrogenation of propylene, but the hydrogenolysis of propylene or propane also slightly proceeds at high temperatures. It was revealed that hydrogen sulfide acts as a hydrogen donating agent for olefins in the reaction of olefins with hydrogen sulfide over sulfided $\mathrm{Mo} / \mathrm{Al}_{2} \mathrm{O}_{3}$ catalyst.

In the previous section 3.1, the author and associates described that the coordinatively unsaturated site on $\mathrm{MoS}_{2}$ surface acts as active site for catalytic decomposition of hydrogen sulfide. Thus, the author and associates concluded that the coordinatively unsaturated site of $\mathrm{MoS}_{2}$ in the sulfided $\mathrm{Mo} / \mathrm{Al}_{2} \mathrm{O}_{3}$ catalyst also acts as active site for the hydrogenation of olefins with hydrogen sulfide. We advanced the following mechanism for the hydrogenation of olefins with hydrogen sulfide over sulfided $\mathrm{Mo} / \mathrm{Al}_{2} \mathrm{O}_{3}$ catalyst:

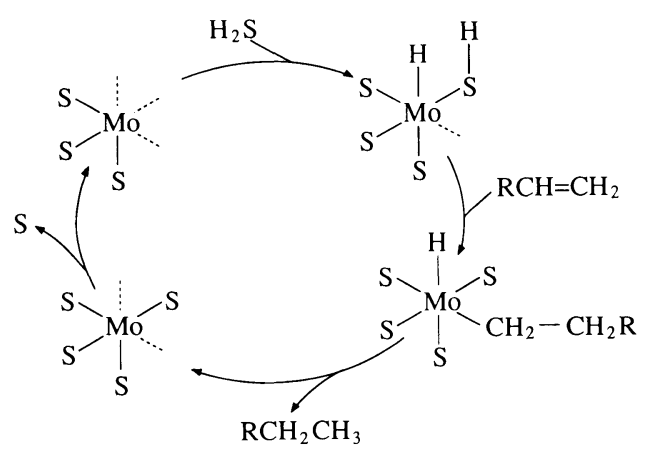

On the other hand, the hydrogenolysis of propylene also proceeded in the reaction of propylene with hydrogen sulfide over sulfided $\mathrm{Mo} / \mathrm{Al}_{2} \mathrm{O}_{3}$ catalyst at $400{ }^{\circ} \mathrm{C}$. It is supposed that

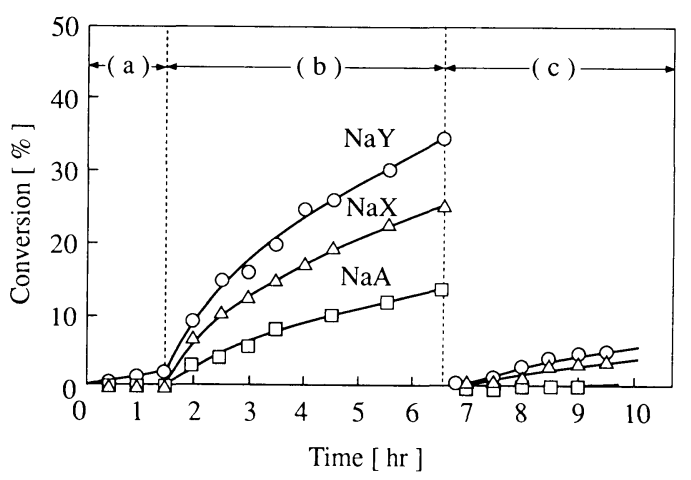

(a): without $\mathrm{H}_{2} \mathrm{~S}$, (b): with $\mathrm{H}_{2} \mathrm{~S}$, (c): without $\mathrm{H}_{2} \mathrm{~S}$ after evacuation at $500^{\circ} \mathrm{C}$ for $2 \mathrm{~h}$

Fig. 10 Effect of Addition of Hydrogen Sulfide on the Catalytic Activity of Various Na Zeolites for the Cracking of $n$-Butane at $500^{\circ} \mathrm{C}$

the hydrogenolysis of propylene at an elevated temperature is attributed to the attack of hydrogen radical or active hydrogen formed by the decomposition of hydrogen sulfide over $\mathrm{MoS}_{2}$ surface, as in the case of liquefaction of coal with hydrogen sulfide over iron sulfide catalyst ${ }^{38}$.

\subsection{Promotive Effect of Hydrogen Sulfide for Hydrocarbon Conversions over Heterogeneous Catalysts}

Recently, it has been revealed that some heterogeneous catalytic reactions are remarkably promoted by the presence of hydrogen sulfide ${ }^{38}$. The author and associates studied the promotional effect of hydrogen sulfide on the cracking of $n$ butane over sodium zeolites ( $\mathrm{NaZ}, \mathrm{Z}=\mathrm{X}, \mathrm{Y}$ and $\mathrm{A})$. It was found that hydrogen sulfide remarkably promotes the catalytic cracking of $n$-butane over $\mathrm{NaZ}{ }^{28)}$, 29).

The catalytic cracking of $n$-butane over $\mathrm{Na}$ zeolites at $500^{\circ} \mathrm{C}$ by use of a closed circulation system is shown in Fig 10. The Na zeolites showed very low activity in the cracking of $n$-butane at $500^{\circ} \mathrm{C}$ in the absence of hydrogen sulfide. The cracking of $n$-butane over $\mathrm{Na}$ zeolites, however, were remarkably accelerated by the presence of hydrogen sulfide. After conducting the cracking reaction for $5 \mathrm{~h}$, all components in the gas phase were evacuated for $2 \mathrm{~h}$ and then the cracking reaction without hydrogen sulfide was carried out again. These $\mathrm{Na}$ zeolites showed very low activity just as in the first run. This indicates that the promoting action of hydrogen sulfide is completely reversible. The products of $n$-butane cracking over these $\mathrm{Na}$ zeolites were $\mathrm{C}_{1}-\mathrm{C}_{3}$ hydrocarbons.

The isomerization of cyclopropane, which proceeds predominantly on the Brönsted acid site of solid acid catalysts, was carried out at $150^{\circ} \mathrm{C}$ over these $\mathrm{Na}$ zeolites to gain more definite knowledge 

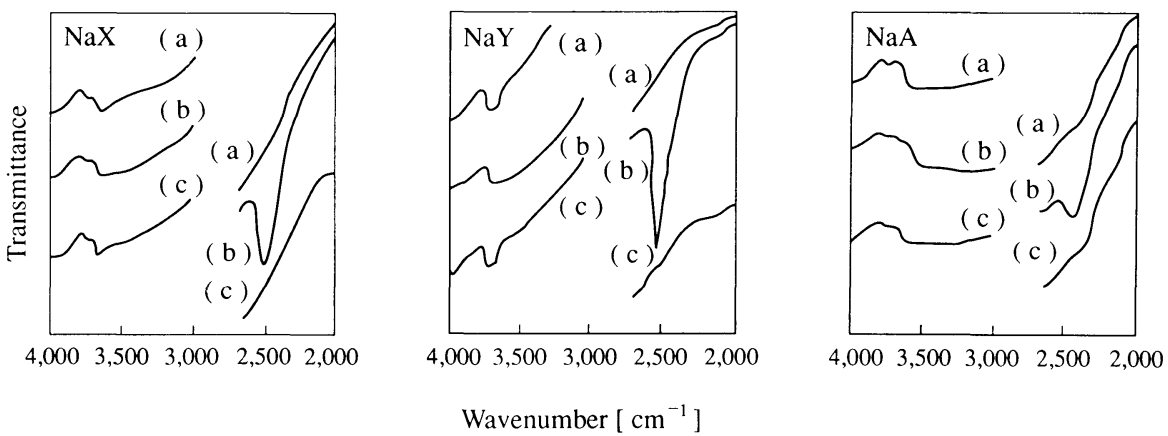

(a): background evacuated at $500^{\circ}$ for $2 \mathrm{~h}$, (b): after introduction of hydrogen sulfide at $500^{\circ} \mathrm{C}$, (c):after evacuation at $500^{\circ} \mathrm{C}$

Fig. 11 IR Spectra of Hydrogen Sulfide Adsorbed on Various Na Zeolites

on promotional action of hydrogen sulfide. It was revealed that hydrogen sulfide considerably promotes the isomerization of cyclopropane over these $\mathrm{Na}$ zeolites at $150^{\circ} \mathrm{C}$ and the order of enhancement of $\mathrm{Na}$ zeolites activity with hydrogen sulfide was comparable to that in the cracking of $n$-butane at $500{ }^{\circ} \mathrm{C}^{28)}$. These results indicate that hydrogen sulfide which had coexisted in the reaction system formed new Brönsted acid site and the Brönsted acid site formed on $\mathrm{Na}$ zeolites promoted the cracking of $n$-butane and isomerization of cyclopropane.

The infrared spectra of hydrogen sulfide adsorbed on these $\mathrm{Na}$ zeolites were examined in order to clarify the mechanism of formation of new Brönsted acid sites on $\mathrm{Na}$ zeolites with hydrogen sulfide adsorbed on these $\mathrm{Na}$ zeolites evacuated at $500^{\circ} \mathrm{C}$ for $2 \mathrm{~h}$, small absorption band of silanol group were observed at around $3,720 \mathrm{~cm}^{-1}$, as shown in Fig. 11. After introduction of hydrogen sulfide (10 Torr) onto these $\mathrm{Na}$ zeolites at $500^{\circ} \mathrm{C}$, absorption band of acidic hydroxyl groups at around 3,640 and 3,550 $\mathrm{cm}^{-1}$ were not observed but thiol (SH) group was observed at around $2,572 \mathrm{~cm}^{-1}$, as shown in spectra(b). The absorption band of SH group, however, had completely disappeared by the evacuation of hydrogen sulfide in gas phase at $500^{\circ} \mathrm{C}$, as shown in spectra(c). From these results, the author and associates concluded that hydrogen sulfide is reversibly adsorbed on sodium ions in $\mathrm{Na}$ zeolite without dissociation, and hydrogen atom of $\mathrm{SH}$ group in the adsorbed hydrogen sulfide molecule on $\mathrm{Na}$ zeolites acts as the Brönsted acid sites in the cracking of $n$-butane and isomerization of cyclopropane as shown below:

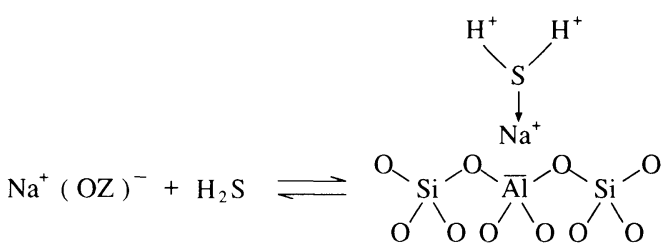

( 5 )

It was revealed that hydrogen sulfide adsorbed reversibly on alkali metal ions in alkali metal zeolites forms new Brönsted acid sites and remarkably accelerates the catalytic hydrocarbon conversions on alkali metal zeolites. This specific property of hydrogen sulfide should be widely applicable for some processes in the petroleum industry.

3.4 Enhancement of Catalytic Activity and Selectivity by Pretreatment with Hydrogen Sulfide

The author and associates investigated the effect of pretreatment with hydrogen sulfide on various heterogeneous catalysts, and found that hydrogen sulfide adsorbed irreveribly on certain kinds of metal ion-exchanged zeolites(MeY) considerably enhances the catalytic activities of $\mathrm{MeY}$ in some acid-catalyzed reactions such as the cracking of cumene and hexane, disproportionation of toluene, dehydration of 2-propanol, isomerization of xylene, butene and cyclopropane, etc. ${ }^{30) ~ 39)}$.

The catalytic activities of various MeY zeolites for cracking of cumene before and after the pretreatment with hydrogen sulfide at $300^{\circ} \mathrm{C}$ using a pulse reactor are shown in Table 1 . Activities of $\mathrm{NaY}, \mathrm{CaY}, \mathrm{BaY}, \mathrm{MgY}, \mathrm{CrY}$ and $\mathrm{ZnY}$ were hardly changed by the pretreatment with hydrogen sulfide, but those of CdY, NiY, CuY, $\mathrm{AgY}$ and CoY were remarkably enhanced by this treatment as shown in Table 1. It was revealed 
Table 1 Initial Activities of Various Metal Ion-exchanged Y Zeolite Catalysts for Cumene Cracking at $300^{\circ} \mathrm{C}$

$\mathrm{H}_{2} \mathrm{~S}$ pretreatment temperature $=300^{\circ} \mathrm{C}$, Amount of $\mathrm{H}_{2} \mathrm{~S}$ injection $=2 \mathrm{ml}\left(8.3 \times 10^{-5} \mathrm{~mol}\right)$, Carrier gas $\mathrm{flow} \mathrm{rate}=27 \mathrm{~m} l / \mathrm{min}$, Volume of cumene pulse $=2 \mu l$

\begin{tabular}{|c|c|c|c|c|c|c|}
\hline Catalyst & $\begin{array}{c}\% \text {-Ion } \\
\text { exchanged }\end{array}$ & $\begin{array}{c}k_{0} \times 10^{-2 \mathrm{a})} \\
{[\mathrm{ml} / \mathrm{g} \cdot \mathrm{min}]}\end{array}$ & $\begin{array}{c}k_{t} \times 10^{-2 \mathrm{~b})} \\
{[\mathrm{ml} / \mathrm{g} \cdot \mathrm{min}]}\end{array}$ & $k_{t} / k_{0}{ }^{c)}$ & $\begin{array}{c}v \times 10^{4 \mathrm{~d})} \\
{[\mathrm{mol} / \mathrm{g}-\mathrm{cat}]}\end{array}$ & $\mathrm{HSAB}^{\mathrm{e}}$ \\
\hline $\mathrm{NaY}$ & - & 0 & 0 & - & $<0.1$ & $\mathrm{H}$ \\
\hline $\mathrm{CaY}$ & 73.8 & 5.1 & 5.1 & 1.0 & $<0.1$ & $\mathrm{H}$ \\
\hline $\mathrm{BaY}$ & 79.5 & 0 & 0 & - & $<0.1$ & $\mathrm{H}$ \\
\hline $\mathrm{MgY}$ & 69.2 & 4.6 & 4.5 & 1.0 & $<0.1$ & $\mathrm{H}$ \\
\hline $\mathrm{MnY}$ & 69.3 & 4.9 & 5.1 & 1.0 & $<0.1$ & $\mathrm{H}$ \\
\hline $\mathrm{PbY}$ & 90.6 & 0 & 0 & - & $<0.1$ & M \\
\hline $\mathrm{FeY}$ & 92.9 & 0 & 0 & - & $<0.1$ & $\mathrm{H}$ \\
\hline CrY & 98.3 & 0 & 0 & - & $<0.1$ & $\mathrm{H}$ \\
\hline $\mathrm{CdY}$ & 75.2 & 2.9 & 15.9 & 5.5 & 5.7 & $S$ \\
\hline $\mathrm{CuY}$ & 77.3 & 3.1 & 16.5 & 5.3 & 5.6 & M \\
\hline $\mathrm{NiY}$ & 68.8 & 3.1 & 15.7 & 5.1 & 6.0 & M \\
\hline $\operatorname{AgY}$ & 93.9 & 2.0 & 9.2 & 4.6 & 10.3 & $S$ \\
\hline COY & 71.4 & 5.2 & 12.8 & 2.5 & 3.6 & M \\
\hline $\mathrm{ZnY}$ & 78.6 & 12.9 & 17.1 & 1.3 & $<0.1$ & M \\
\hline
\end{tabular}

a) : First-order rate constant before pretreatment with $\mathrm{H}_{2} \mathrm{~S}$

b) : First-order rate constant after pretreatment with $\mathrm{H}_{2} \mathrm{~S}$

c) : Ratio of activity increase

d) : Amount of $\mathrm{H}_{2} \mathrm{~S}$ adsorbed on MeY

e) : Hard and soft acid and base

that the affinity of metal ions in MeY for hydrogen sulfide is very important for the increase of catalytic activity of $\mathrm{MeY}$ by pretreatment with hydrogen sulfide. The symbols of HSAB(Hard and Soft Acids and Bases) are also shown in Table 1. According to HSAB concept, hydrogen sulfide is classified as soft base and it has tendency to combine with soft or medium metal ions. As can be seen in Table 1, all MeY zeolites, which activities were remarkably enhanced by pretreatment with hydrogen sulfide, contained soft or medium metal ions in MeY. Therefore, the author and associates concluded that marked increase in activity of $\mathrm{MeY}$ zeolites by the pretreatment with hydrogen sulfide is attributed to strong interaction of metal ions in MeY with hydrogen sulfide.

The infrared spectra of MeY (CdY, NiY, CuY, $\mathrm{AgY}, \mathrm{CoY}$ and $\mathrm{ZnY}$ ) after adsorption of hydrogen sulfide were examined to clarify the mechanism of enhancement effect of hydrogen sulfide on catalytic activities of these MeY zeolites. The infrared spectra of these MeY, before and after the adsorption of hydrogen sulfide, are shown in Fig. 12. In the background infrared spectra of these MeY, weak intensity absorption band of surface acidic hydroxyl groups, i.e., Brönsted acid site, at 3,640 and $3,545 \mathrm{~cm}^{-1}$, were observed. The intensities of these two acidic hydroxyl groups on all MeY were remarkably increased by the adsorption of hydrogen sulfide. The infrared spectra of newly formed hydroxyl groups on MeY had completely disappeared by the adsorption of pyridine, and the band of pyridinium ion at $1,545 \mathrm{~cm}^{-1}$ was observed. These results indicate clearly that the newly formed hydroxyl groups on MeY, as well as those on $\mathrm{HY}$ zeolite, after adsorption of hydrogen sulfide have

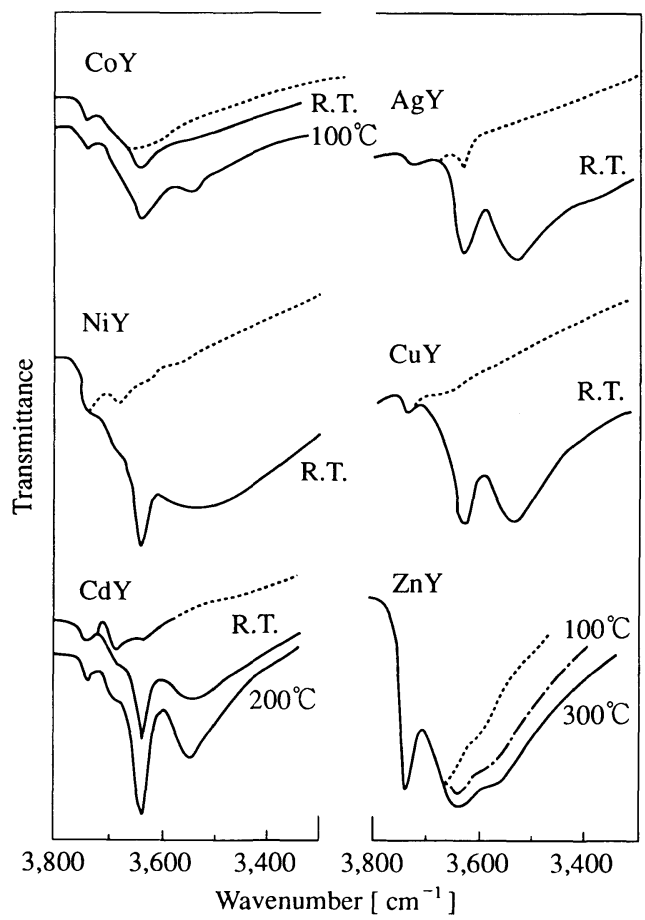

Dotted line represents background of MeY.

R. T.: room temperature

Fig. 12 IR Spectra of Various MeY Zeolites after Adsorption of Hydrogen Sulfide

strong acidic nature.

From these results, the author and associates concluded that new Brönsted acid sites are formed on these MeY zeolites by the pretreatment with hydrogen sulfide ${ }^{36}$, and advanced the following mechanism for the formation of new Brönsted acid sites on MeY zeolites by the pretreatment with hydrogen sulfide: 


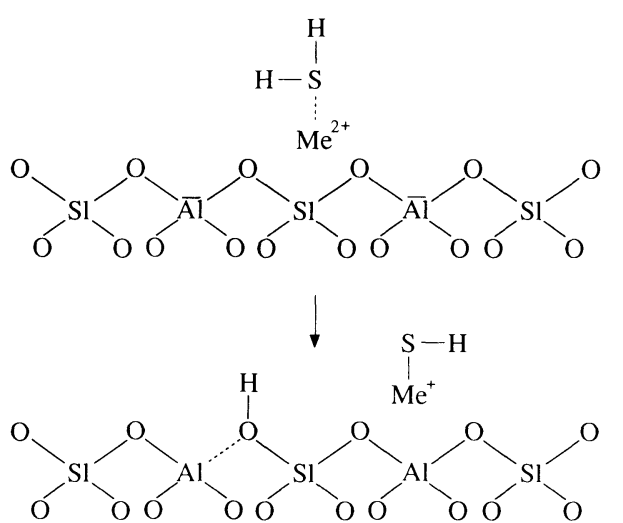<smiles>[Y5]O[Si](O)(O[Al](O)(O)O[Si](O)(O)O)O[Si](O)(O)O[Al](O)(O)O</smiles><smiles>[Y16]S[Al](O)(O)O[Si](O)(O)O[Al](O)(O)O[Si](O)(O)O</smiles>

By this mechanism, hydrogen sulfide is adsorbed on metal ion in MeY zeolites and dissociates to form acidic hydroxyl groups and metal sulfide particles.

Furthermore, the author and associates revealed that high activity and selectivity to trans-2-butene in the isomerization of l-butene were obtained over sulfided metal ion-exchanged A zeolite (MeA) with hydrogen sulfide ${ }^{40), 41)}$. The catalytic isomerization of 1-butene over CoA and sulfided CoA zeolites $^{40}$ ) at room temperature by use of a closed circulation system are shown in Fig. 13. CoA zeolites without sulfiding showed no catalytic activity in the isomerization of l-butene. The catalytic activity of CoA zeolite, however, was remarkably enhanced by sulfiding with hydrogen sulfide at $300^{\circ} \mathrm{C}$ as shown in Fig. 13. Enhanced activity of CoA zeolite was found to be higher than that of $\mathrm{HY}$ zeolite. The isomerization of 1-butene over sulfided CoA zeolite was highly selective for the formation of trans-2-butene. A selectivity of above $90 \%$ was obtained constantly during the reaction. The high activity of CoA zeolite enhanced by sulfiding with hydrogen sulfide might be attributed to the formation of new Brönsted acid site on CoA zeolite surface just as in the case of MeY zeolites ${ }^{35}$. The high selectivity of sulfided CoA zeolite for the formation of trans-2-butene could be attributed to the action of shape selectivity of CoA zeolite with

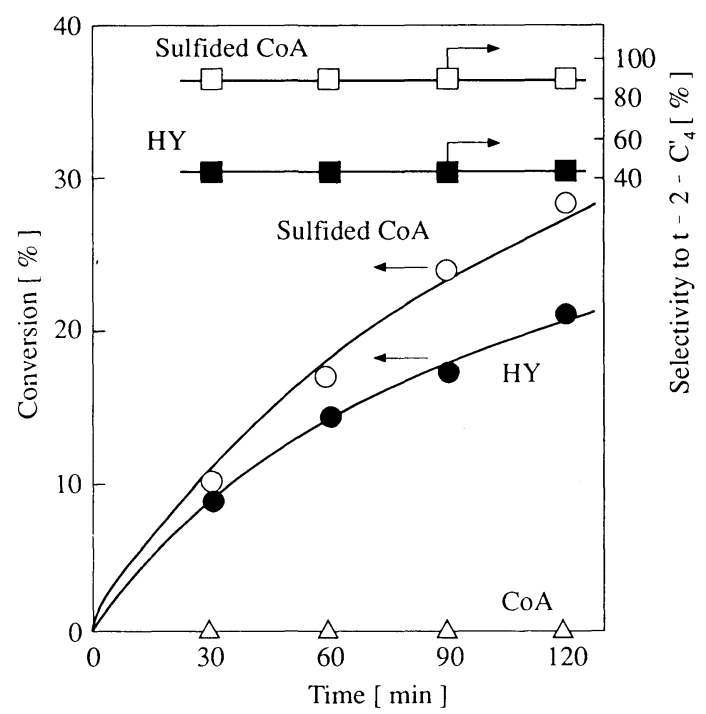

Fig. 13 Catalytic Isomerization of 1-Butene over CoA and Sulfided CoA Zeolites at Room Temperature

Table 2 Hydrogenation of Various Olefins over Highly Active Sulfided $\mathrm{Mo} / \mathrm{Al}_{2} \mathrm{O}_{3}$ Catalyst

\begin{tabular}{|c|c|c|c|}
\hline Olefin & $\begin{array}{l}\text { Reaction } \\
\text { temp. }\left[{ }^{\circ} \mathrm{C}\right]\end{array}$ & $\begin{array}{l}\text { Reaction } \\
\text { time[min] }\end{array}$ & $\begin{array}{c}\text { Conversion } \\
{[\%]}\end{array}$ \\
\hline Ethylene $^{\text {a) }}$ & $\begin{array}{r}0 \\
-47 \\
-75\end{array}$ & $\begin{array}{r}5 \\
15 \\
15\end{array}$ & $\begin{array}{l}100 \\
100 \\
100\end{array}$ \\
\hline Propylene $^{a)}$ & $\begin{array}{r}5 \\
-46\end{array}$ & $\begin{array}{l}15 \\
30\end{array}$ & $\begin{array}{l}100 \\
100\end{array}$ \\
\hline 1-Butene ${ }^{a)}$ & 0 & 15 & 100 \\
\hline 1,3-Butadiene ${ }^{\text {b) }}$ & $\begin{array}{r}4 \\
-20\end{array}$ & $\begin{array}{l}20 \\
35\end{array}$ & $\begin{array}{l}100 \\
100\end{array}$ \\
\hline
\end{tabular}

a) $\mathrm{H}_{2}$ : olefin=10 Torr : 10 Torr

b) $\mathrm{H}_{2}$ : olefin=20 Torr : 10 Torr; only butane was formed.

small pore diameter. That is to say, since the diffusion rate of cis-2-butene is two orders of magnitude lower than that of trans-2-butene, cis-2butene can not easily diffuse from the super cage to the outer surface at room temperature, even if cis-2-butene is formed inside the super cage of sulfided CoA in the isomerization of l-butene.

On the other hand, the author and associates tried to prepare highly active sulfided $\mathrm{Mo} / \mathrm{Al}_{2} \mathrm{O}_{3}$ catalyst by sulfiding with hydrogen sulfide, and found that extremely high active sulfided $\mathrm{Mo} /$ $\mathrm{Al}_{2} \mathrm{O}_{3}$ catalyst for the hydrogenation of olefins could be prepared by sulfiding $\mathrm{Mo} / \mathrm{Al}_{2} \mathrm{O}_{3}$ with hydrogen sulfide followed by evacuation under high vacuum $\left(10^{-5}\right.$ Torr) at high temperature $\left(450^{\circ} \mathrm{C}\right)^{42)}$. The activity of sulfided $\mathrm{Mo} / \mathrm{Al}_{2} \mathrm{O}_{3}$ catalysts followed by evacuation under $10^{-5}$ Torr at $450^{\circ} \mathrm{C}$ for the hydrogenation of various olefins are shown in Table 2, and it can be seen that sulfided $\mathrm{Mo} / \mathrm{Al}_{2} \mathrm{O}_{3}$ catalyst thus prepared showed extremely high activity in the hydrogenation of 
various olefins, even at low temperatures. The author and associates concluded that the extremely powerful activity of highly active sulfided Mo/ $\mathrm{Al}_{2} \mathrm{O}_{3}$ catalyst for use in the hydrogenation of olefins could be attributed to the formation of highly dispersed $\mathrm{MoS}_{2}$ with low coordination number on sulfided $\mathrm{Mo} / \mathrm{Al}_{2} \mathrm{O}_{3}$ catalyst. This method of preparation of highly active sulfided $\mathrm{Mo} / \mathrm{Al}_{2} \mathrm{O}_{3}$ catalyst would be available for the development of highly active $\mathrm{MoS}_{2}$ based hydrodesulfurization catalyst for the treatment of petroleum feedstocks.

\section{Conclusion}

In those systematic studies with respect to the catalytic hydrodesulfurization of organic sulfur compounds and the effective usage of hydrogen sulfide, the author and associates found that reduced MeY zeolites are powerful as highly active hydrodesulfurization catalysts for the treatment of petroleum feedstocks, and also revealed that hydrogen sulfide has many possibilities as useful chemicals for the petroleum industry.

\section{References}

l) Sugioka, M., Yotsuyanagi, T., Aomura, K., Kogyo Kagaku Zasshi, 73, (10), 2172 (1970).

2) Sugioka, M.,Hirano, T., Yotsuyanagi, T., Aomura, K., Kogyo Kagaku Zasshi, 73, (10), 2176 (1970).

3) Sugioka, M., Hirano, T., Aomura, K., Nippon Kagaku Kaishi, 1972, 1597.

4) Sugioka, M., Aomura, K., Nippon Kagaku Kaishi, 1973, 471 .

5) Sugioka, M., Aomura, K., Bull. Japan Petrol. Inst., 15, (2), 36 (1973).

6) Sugioka, M., Aomura, K., Nippon Kagaku Kaishi, 1973, 1279.

7) Sugioka, M., Aomura, K., Intern. Chem. Eng., 13, (4), 755 (1973).

8) Sugioka, M., Aomura, K., Bull. Japan Petrol. Inst., 17, (1), 51 (1975).

9) Sugioka, M., Kamanaka, T., Aomura, K., Bull. Japan Petrol. Inst., 18, (1), 14 (1976).

10) Kamanaka, T., Sugioka, M., Aomura, K., Nippon Kagaku Kaishi, 1976, 1156.

11) Kamanaka, T., Sugioka, M., Aomura, K., Bull. Japan Petrol. Inst., 19, (1), 4 (1977).

12) Sugioka, M., Kamanaka, T., Aomura, K., J. Catal., 52, (3), 531 (1979)

13) Sugioka, M., Aomura, K., Nippon Kagaku Kaishi, 1978, 1153.

14) Sugioka, M., Kamanaka, T., Aomura, K., Preprints, Am.
Chem. Soc, Div Petrol Chem, 24, (2), 740 (1979).

15) Sugioka, M., Hirano, T., Yotsuyanagi, T., Aomura, K., Kogyo Kagaku Zasshi, 74, (1), 129 (1971).

16) Sugioka, M., Kobayashi, E., Sano, M., Yotsuyanagi, T., Aomura, K., Kogyo Kagaku Zasshi, 74, (7), 1492 (1971).

17) Sugioka, M., Aomura, K., Bull. Fac. Eng., Hokkaido Univ., No. 69, 231 (1973).

18) Sugioka, M., Aomura, K., Preprints, Am. Chem. Soc., Div. Petrol. Chem., 25, (2), 245 (1980).

19) Sugioka, M., Aomura, K., Bull. Fac. Eng., Hokkaido Univ., No. 99, 79 (1980)

20) Sugioka, M., Aomura, K., Sekiyu Gakkaishi, 26, (3), 216 (1983).

21) Sugioka, M., Sasaki, M., Aomura, K., Sekiyu Gakkaishi, 26, (3), 221 (1983).

22) Sugioka, M., Sasaki, M., Aomura, K., Sekiyu Gakkaishi, 26, (5),362 (1983).

23) Sugioka, M., Sasaki, M., Aomura, K., Sekiyu Gakkaishi, 26, (5), 477 (1983).

24) Sugioka, M., Aomura, K., Proc. 5th World Hydrogen Energy Conference, 2, 477 (1984).

25) Sugioka, M., Aomura, K., Intern. J. Hydrogen Energy, 9, (11), 891 (1984).

26) Sugioka, M., Kanazuka, T., Nippon Kagaku Kaishi, 1988, 1294.

27) Sugioka, M., Kimura, F., Sekiyu Gakkaishi, 28, (3), 270 (1985).

28) Sugioka, M., Nakayama, T., Uemichi, Y., Kanazuka, T., React. Kinet. Catal. Lett., 41, 345 (1990).

29) Sugioka, M., Nakayama, T., Amisawa, Y., Uemichi, Y., Kanazuka, T., Abst. 1st Tokyo Conference on Advanced Catalytic Science \& Technology, 169 (1990).

30) Sugioka, M., Hosotsubo, T., Aomura, K., J. Chem. Soc., Chem. Comm., 54 (1976).

31) Hosotsubo, T., Sugioka, M., Sanada, Y., Aomura, K., Nippon Kagaku Kaishi, 1979, 28.

32) Hosotsubo, T., Sugioka, M., Sanada, Y., Aomura, K., Sekiyu Gakkaishi, 23, (3), 189 (1980).

33) Hosotsubo, T., Sugioka, M., Sanada, Y., Aomura, K., Nippon Kagaku Kaishi, 1980, 797.

34) Sugioka, M., Hosotsubo, T., Aomura, K., Sekiyu Gakkaishi, 27, (6), 564 (1984)

35) Sugioka, M., Hyōmen (Surface), 25, (9), 522 (1987).

36) Sugioka, M., Nakayama, S., Kanazuka, T., Hosotsubo, T., Proc. Intern. Symp. on Acid-Base Catalysis, 305 (1989).

37) Sugioka, M., Nakayama, S., Nakayama, T., Kanazuka, T., Proc. 4th Japan-China-USA Symp. on Catalysis, 286 (1989).

38) Sugioka, M., Shokubai (Catalyst), 31, (7), 525 (1989).

39) Sugioka, M., Nakayama, S., Kanazuka, T., Abst. 1989 Chem. Congr. Pacific Basin Societies, phys-257, (1989).

40) Sugioka, M., Nakayama, S., Uchida, D., Kanazuka, T., Chem. Lett., 1989, 1967.

41) Sugioka, M., Nakayama, S., Uchida, D., Kanazuka, T., Abst. Intern. Symp. on Chemistry of Microporous Crystals, 129 (1990).

42) Sugioka, M., Kanazuka, T., Chem. Lett., 1988, 393. 
要旨

\title{
高活性脱硫触媒の開発と副生硫化水秦の有効利用
}

\author{
杉岡 正敏
}

室蘭工業大学応用化学科, 050 室蘭市水元町 27 番 1 号

新規の高活性脱硫触媒を開発することは, 燃料油の燃焼によ り排出される硫黄酸化物を低隇するために極めて重要である。 一方, 燃料油の脱硫では大量の硫化水素が副生する。現在副生 する硫化水素はクラウス反応により単体硫黄と水とに変換さ れ, 単体硫黄のみが回収されている。しかし, 経済的見地か ら, 将来は副生する硫化水素を積極的に有効利用することも重 要な課題となるものと考えられる。本総合論文では著者および 共同研究者がこれまでに行ってきた高活性脱硫触媒の開発およ び副生硫化水素の有効利用に関する系統的研究を述べた。

著者らは新規の高活性脱硫触媒として水素還元処理した金属 イオン交換 $\mathrm{Y}$ 型ゼオライト $\left(\mathrm{Me}^{\circ} \mathrm{Y}\right)$ 触媒に注目し, 脱硫反応 のモデル反応であるチオフェンの水素化脱硫反応に対する種々 の $\mathrm{Me}^{\circ} \mathrm{Y}$ 触媒の活性を検討した。この結果, $\mathrm{Ni}^{\circ} \mathrm{Y}$ および $\mathrm{Co}^{\circ} \mathrm{Y}$ などの $\mathrm{Me}^{\circ} \mathrm{Y}$ 触媒はチオフェンの水素化脱硫反応に対し て市販の $\mathrm{CoMo} / \mathrm{Al}_{2} \mathrm{O}_{3}$ 系脱硫触媒よりも著しく高い活性を示 した (Figs. 1, 2)。また, $\mathrm{Me}^{\mathrm{o}} \mathrm{Y}$ 上に吸着したチオフェンの赤 外吸収スペクトルなどから, $\mathrm{Me}^{\circ} \mathrm{Y}$ 触媒はチオフェンの水素化 脱硫反応に対して二元機能触媒として作用することが明らかと なった (Fig. 3)。これらのことから, $\mathrm{Me}^{\circ} \mathrm{Y}$ 系触媒は新規の
高活性脱硫触媒として高い可能性を有しているものと考えられ た。

一方，アルミナ担持 $\mathrm{MoS}_{2}$ 系触媒は硫化水素の接触分解に よる水素生成に対して有効な触媒として作用し, 硫化水素の接 触分解による水素と硫黄の同時回収が可能であることが明らか となった（Figs. 4〜7）。また, 硫化処理した $\mathrm{Mo} / \mathrm{Al}_{2} \mathrm{O}_{3}$ 触媒 上では硫化水素によるオレフィンの水素化が進行し，硫化水素 による不飽和炭化水素の接触水素化反応が可能であることが明 らかとなった（Figs. 8,9)。さらに，非酸性のアルカリ金属ゼ オライト触媒による炭化水素の接触転化反応において, 反応系 に硫化水素が共存すると転化反応が著しく促進されることがわ かった（Figs. 10, 11)。最後に金属イオン交換ゼオライト触 媒打よび担持 Mo 触媒を硫化水素で硫化処理すると, 炭化水 素の種々の反応に対する触媒機能が著しく向上することが明ら かとなった（Tables 1, 2, Figs. 12,13）。このように，脱硫 反応で副生する硫化水素を不均一系触媒反応の技術を応用し て，種々のプロセスに有効利用することが可能であることが明 らかとなった。

\section{Keywords}

Hydrodesulfurization, Catalyst design, Y zeolite, Thiophene, Hydrogen sulfide 